Thea Berends for carrying out the therapy; and Judith Prins for her contribution to the study design.

Contributors: See bmj.com

Funding: Foundation for Children's Welfare Stamps Netherlands (Stichting Kinderpostzegels Nederland) and the ME Society (ME Stichting).

Competing interests: None declared.

Ethical approval: Human Ethics Committee of the University Medical Centre Nijmegen.

1 Fukuda K, Straus SE, Hickie I, Sharpe MC, Dobbins JG, Komaroff A, et al. The chronic fatigue syndrome: a comprehensive approach to its definition and study. Ann Intern Med 1994;121:953-9.

2 Reeves WC, Lloyd A, Vernon SD, Klimas N, Jason LA, Bleijenberg G, et al. Identification of ambiguities in the 1994 chronic fatigue syndrome research case definition and recommendations for resolution. $B M C$ Health Serv Res 2003;3:25-33.

3 Chalder T, Goodman, R, Wessely, S, Hotopf M, Meltzer H. Epidemiology of chronic fatigue syndrome and self reported myalgic encephalomyelitis in 5-15 year olds: cross sectional study. BMJ 2003;327:654-5

4 Prins JB, Bleijenberg G, Bazelmans E, Elving LD, de Boo Th, Severens JL, et al. Cognitive behaviour therapy for chronic fatigue syndrome: a multicentre randomised controlled trial. Lancet 2001;357:841-7.

5 Whiting P, Bagnall, A, Sowden AJ, Cornell JE, Mulrow CD, Ramirez G. Interventions for the treatment and management of CFS. JAMA 2001;286:1360-8

6 Chalder T, Tong J, Deary V. Family cognitive behaviour therapy for chronic fatigue syndrome: an uncontrolled study. Arch Dis Child 2002;86:95-7.
7 Garralda ME, Rangel L. Annotation: chronic fatigue syndrome in children and adolescents. J Child Psychol Psychiatry 2002;43:169-76.

8 Carter BD, Edwards JF, Kronenberger WG, Michalczyk L, Marshall GS. Case control study of chronic fatigue in pediatric patients. Pediatrics 1995;95:179-86.

9 Fritz U, McQuaid EL. Chronic medical conditions. Impact on development. In: Sameroff AJ, Lewis M, Miller SM, eds. Handbook of developmental psychopathology. New York: Kluwer, 2000.

10 Van der Werf SP, Prins JB, Vercoulen JHMM, van der Meer JWM, Bleijenberg G. Identifying physical activity patterns in chronic fatigue syndrome using actigraphic assessment.J Psychosom Res 2000;49:372-9.

11 Bleijenberg G, Prins J, Bazelmans E. Cognitive-behavioral therapies. In: Jason LA, Fennel PA, Taylor RR, eds. Handbook of chronic fatigue syndrome. New Jersey: John Wiley, 2003.

12 Vercoulen JHHM, Swanink CMA, Galama JMD, Fennis JFM, van der Meer JWM, Bleijenberg G. Dimensional assessment in chronic fatigue syndrome.J Psychosom Res 1994;38:383-92.

13 Beurskens AJHM, Bültmann U, Kant IJ, Vercoulen JHMM, Bleijenberg G, Swaen GMH. Fatigue amongst working people: validity of a questionnaire. Occup Environm Med 2000;57:353-7.

14 Faul F, Erdfelder E, Gpower: a priori, post-hoc, and compromise power analyses for MS-DOS [computer program]. Bonn, FRG: Bonn University, Department of Psychology, 1992.

15 Bell DS, Jordan K, Robinson M. Thirteen-year follow-up of children and adolescents with chronic fatigue syndrome. Pediatrics 2001;107: 994-8.

16 Gill AC, Dosen A, Ziegler JB. Chronic fatigue in adolescents: a follow-up study. Arch Pediatr Adolesc Med 2004;158:225-9.

(Accepted 7 October 2004)

doi $10.1136 /$ bmj.38301.587106.63

\title{
Insulin resistance and depression: cross sectional study
}

Markku Timonen, Mauri Laakso, Jari Jokelainen, Ulla Rajala, V Benno Meyer-Rochow, Sirkka Keinänen-Kiukaanniemi

A recent study found that depression is inversely associated with insulin resistance, but positively associated with diabetes. ${ }^{1}$ Association between insulin resistance and depression is a poorly studied area and the few earlier findings do not necessarily support this finding, ${ }^{1}$ indicating that patients with serious depression have insulin resistance assessed by insulin tolerance, intravenous, or oral glucose tolerance tests. ${ }^{2}$ Recently, depression was found to be associated with greater insulin resistance in women with polycystic ovary syndrome. ${ }^{3}$ Also, more than the normal rates of depression had already been noted in patients with clinically manifest diabetes. ${ }^{2}$ Since insulin resistance is positively associated with the development of diabetes, ${ }^{1}$ we hypothesised-given that disturbed glucoregulatory functions behind the development of diabetes might be associated with pathophysiological changes in depression ${ }^{2}$-that insulin resistance should be positively correlated with depressive symptoms. We also investigated whether depressive symptoms varied with different levels of a disturbed glucose metabolism.

\section{Participants, methods, and results}

We invited all 1008 people born in 1935 and living in the city of Oulu, Finland, on 1 October 1990 to participate in a study to assess the prevalence of type 2 diabetes and impaired glucose tolerance; 831 attended. The follow up of the earlier participants, on which this study was based $(n=593)$, was done in 1996-1998; we excluded patients previously diagnosed as having diabetes, leaving 491 cases. A detailed description of

\section{What is already known on this topic}

More than normal rates of depression can already be detected in patients with clinically manifest diabetes

The association between insulin resistance and depression is a sparsely studied area, and the few existing findings are contradictory

\section{What this study adis}

A positive correlation between insulin resistance and severity of depressive symptoms is present already in subjects with impaired glucose tolerance before the outbreak of type 2 diabetes mellitus

the data was given earlier. ${ }^{4}$ We defined insulin resistance with the qualitative insulin sensitivity check index, ${ }^{4}$ and we evaluated the severity of depressive symptoms with Beck's depression inventory $21 .^{5}$ We found a negative correlation between the scores (Spearman correlation coefficient $r=-0.13$, $\mathrm{P}=0.004$ ). The correlation (see figure on bmj.com) was most evident in subjects with impaired glucose tolerance $(\mathrm{r}=-0.24, \quad \mathrm{P}=0.029 ;$ table $)$. Regarding

This article was posted on bmj.com on 16 December 2004: http://bmj.com/cgi/doi/10.1136/bmj.38313.513310.F7

\section{A figure showing the results is on bmj.com}

Department of Public Health Science and General Practice, University of Oulu, Box 5000,

FIN-90014, Finland Markku Timonen acting professor Ulla Rajala research fellow

Unit of General Practice, Oulu University Hospital, 90029 OYS, Finland Mauri Laakso senior lecturer Jari Jokelainen biostatistician

International University Bremen, School of

Engineering and Science, D-28725 Bremen, Germany V Benno

Meyer-Rochow

professor

Oulu Health

Centre, Box 8 ,

FIN-90015 City of

Oulu, Finland

Sirkka Keinänen-

Kiukaanniemi

professor

Correspondence to: M Timonen markku.timonen@ oulu.fi

BMJ 2005;330:17-18 
Medians and interquartile ranges of Beck's depression inventory 21 values in different glucose tolerance categories checked by oral glucose tolerance test in elderly Finns

\begin{tabular}{|c|c|c|c|}
\hline & $\begin{array}{l}\text { Normal glucose } \\
\text { tolerance }{ }^{\star}(n=367)\end{array}$ & $\begin{array}{l}\text { Impaired glucose } \\
\text { tolerancet }(n=92)\end{array}$ & $\begin{array}{l}\text { Type } 2 \text { diabetes } \\
\text { mellitus } \neq(\mathrm{n}=32)\end{array}$ \\
\hline $\begin{array}{l}\text { Correlation between qualitative insulin } \\
\text { sensitivity check index and Beck's } \\
\text { depression inventory } 21 \S\end{array}$ & $-0.037 ; P=0.492$ & $-0.24 ; P=0.029$ & Not feasible \\
\hline $\begin{array}{l}\text { Beck's depression inventory } 21 \text { median } \\
\text { (interquartile range) }\end{array}$ & $5.0(2.0-8.0)$ & $6.0(4.0-8.5)$ & $6.0(3.5-8.0)$ \\
\hline Difference in median (95\% confidence interval) & Control & 1 (0 to 2$)$ & 1 (-1 to 2$)$ \\
\hline \multirow[t]{2}{*}{ Wilcoxon rank-sum test $\mathrm{P}$ value } & Control & 0.015 & 0.380 \\
\hline & & Control & 0.639 \\
\hline
\end{tabular}

* People with fasting glucose concentration of $<6.1 \mathrm{mmol} / \mathrm{l}$ and 2 hour blood glucose concentration of $<7.8$ $\mathrm{mmol} / \mathrm{l}$ in oral glucose tolerance test. Thus the normal glucose tolerance group includes also those with impaired fasting glucose (fasting glucose concentration $5.6-6.0 \mathrm{mmol} / \mathrm{l}$ ).

†People with a fasting glucose concentration of $<6.1 \mathrm{mmol} / \mathrm{l}$ and 2 hour blood glucose concentration of

$7.8-11.0 \mathrm{mmol} / \mathrm{l}$ in oral glucose tolerance test.

People with fasting glucose concentration of $\geq 6.1 \mathrm{mmol} / \mathrm{l}$ or 2 hour blood glucose concentration of $\geq 11.1$ $\mathrm{mmol} / \mathrm{l}$ in oral glucose tolerance test.

§Spearman partial correlation coefficient between qualitative insulin sensitivity check index and Beck's depression inventory 21 scores adjusting for body mass index, smoking, alcohol consumption, physical inactivity, sex, and basic education.

different levels of disturbed glucose metabolism, patients with type 2 diabetes and impaired glucose tolerance had higher depression scores (median 6.0 and 6.0) than those with normal glucose tolerance (5.0); the difference was statistically significant between impaired and normal glucose tolerance groups (table).

\section{Comment}

Insulin resistance (a low qualitative insulin sensitivity check index) and severity of depressive symptoms (Beck's depression inventory 21) were positively correlated, particularly in people with impaired glucose tolerance. Our findings are at variance with those of Lawlor and colleagues, ${ }^{1}$ who suggested that a clinical diagnosis of diabetes in itself would be an explanation for their findings regarding diabetic patients. With our database, clinical diagnoses could not have affected the results, because we excluded patients previously diagnosed as having diabetes. Because in our study higher depression scores were already prevalent in those with impaired glucose tolerance without clinically manifest diabetes, our findings might be explained biologically - that is, by pathophysiological changes behind insulin resistance and depression.

Insulin resistance could develop as a consequence of an increased release of counter-regulatory hormones associated with depression. ${ }^{2}$ This, however, is unconfirmed. The strengths of our study were that the qualitative insulin sensitivity check index has shown to be a reliable instrument in screening insulin sensitivity in epidemiological studies. ${ }^{4}$ Also this was a population based study consisting of a representative sample of one whole age group. A limitation of our study is that the validity of the findings based on self reported Beck's depression inventory scales is inferior to those of structured diagnostic rating scales; thus, it cannot provide specific depression diagnoses. Neither could we test the causal hypothesis, because we did not know the full history of depression in the participants.

Contributors: MT conceived the study, reviewed the literature, and wrote the initial and subsequent drafts. SKK helped to conceive the study and revise the initial and subsequent drafts, and was overseer of the research group. IJ designed the statistical analyses, analysed the data, developed the figure, and helped draft the manuscript. ML and UR collected the data and contributed to the study design, interpretation, and revisions of the manuscript. VBMR helped revising the initial draft and contributed to revisions and discussions. MT is guarantor.

Funding: No additional funding.

Competing interests: None declared.

Ethical approval: Ethics Committee of the Faculty of Medicine, University of Oulu, Finland.

Lawlor DA, Smith GD, Ebrahim S. Association of insulin resistance with depression: cross sectional findings from the British Women's Heart and Health Study. BMJ 2003;327:1383-4.

2 Musselman DL, Betan E, Larsen H, Phillips LS. Relationship of depression to diabetes types 1 and 2: epidemiology, biology, and treatment. Biol Psychiatry 2003;54:317-29.

3 Rasgon NL, Rao RC, Hwang S, Altshuler LL, Elman S, Zuckerbrow-Mille J, et al. Depression in women with polycystic ovary syndrome: clinical and biochemical correlates. J Affect Disord 2003;74:299-304.

4 Rajala U, Laakso M, Paivansalo M, Pelkonen O, Suramo I, Keinanen-Kiukaanniemi S. Low insulin sensitivity measured by both Keinanen-Kikaanniemi s. Low insulin sensitinty measured by both quantitative in sens

5 Beck AT, Ward CH, Mendelson M, Mock J, Erbaugh J. An inventory for measuring depression. Arch Gen Psychiatry 1961;4:561-71. (Accepted 16 November 2004)

doi 10.1136/bmj.38313.513310.F7
Correspondence to: H Peltola

heikki.peltola@hus.fi

continued over

BMJ 2005;330:18-19

\title{
Incidence of Haemophilus influenzae type b meningitis during 18 years of vaccine use: observational study using routine hospital data
}

\author{
Heikki Peltola, Eeva Salo, Harri Saxén
}

Despite the spectacular success of Haemophilus influenzae type $\mathrm{b}$ (Hib) conjugate vaccines in the developed world, ${ }^{1}$ failures have become more common in the Netherlands and the United Kingdom, where the incidence of invasive Hib diseases at age $0-4$ years per 100000 increased from 0.66 in 1998 to 2.96 in $2001 .^{2}$ An immunological defect is not to blame.

This increase in failure coincided with the change from whole cell pertussis to combined three component acellular vaccine (DTaP-Hib). This combination lowers Hib antibodies. ${ }^{3}$ The clinical significance is unclear. Acellular vaccine cannot be blamed in the Netherlands, where whole cell vaccine was still used. ${ }^{4}$ Both countries have been giving Hib vaccination at age 2, 3, and 4 months; a booster at 11 months is given in the Netherlands. Another characteristic in the United Kingdom is concomitant meningococcal group $\mathrm{C}$

This article was posted on bmi.com on 25 November 2004: http://bmj.com/cgi/doi/10.1136/bmj.38301.657014.79 